\title{
Should Healthcare Organisations Offer Ongoing Rehabilitation Services for Patients Undergoing Haematopoietic Cell Transplant?
}

A Narrative Review

\begin{abstract}
Background and objective

Hematopoietic Cell Transplant (HCT) patients can suffer from long-term transplant-related complications that affect their quality of life and daily activities. This narrative review aims to report the impact of HCT complications, the benefits of rehabilitation intervention, the need for long-term care, and highlight the research gap in clinical trials involving rehabilitation.
\end{abstract}

\section{Methods}

A comprehensive search strategy was performed on several databases to look for relevant articles published from 1998 to 2018. Articles published in English with the following terms were used: Hematopoietic Stem Cell Transplant; Chronic graft versus host disease; Rehabilitation; Exercise; Physical Therapy; Occupational Therapy. A PICO framework (patient/population, intervention, comparison, and outcomes) was employed to ensure that the search strategies were structured and precise. Study year, design, outcome, intervention, sample demographics, setting, and study results were extracted.

\section{Results}

Of the 1411 records identified, 51 studies underwent title/abstract screening for appropriateness, 30 were reviewed in full, and 19 studies were included in the review. The review found that, for the majority of patients who underwent HCT and developed treatmentrelated complications, rehabilitation exercises had a positive impact on their overall quality of 
life. However, exercise prescription in this patient group has not always reflected the scientific approach; there is a lack of high-quality clinical trials in general. The review also highlights the need to educate healthcare policy makers and insurance companies responsible for rationing services to recognise the importance of offering long-term follow up care for this patient group, including rehabilitation services.

\section{Conclusion}

A large number of HCT patients require long-term follow-up from a multidisciplinary team, including rehabilitation specialists. It is important for healthcare policymakers and insurance companies to recognise this need and take the necessary steps to ensure that HSCT patients receive adequate long-term care. This paper also highlights the urgent need for high-quality rehabilitation trials to demonstrate the feasibility and importance of rehabilitation teams.

Keywords: Exercise, Hematopoietic Cell Transplant, Allogeneic, Physiotherapy, Healthcare policy, Occupational therapy

Word Count: 223 


\section{INTRODUCTION}

Haematopoietic Stem Cell Transplants (HSCT) have gained popularity as a treatment of choice in managing both malignant and non-malignant conditions (Copelan, 2006). With the maturity of transplant technology and the growing body of research, overall survival among transplant patients has risen significantly over recent decades (Wingard et al., 2011). However, increased survivorship has also shifted the burden of suffering from diseaseassociated to treatment-related, resulting in long-term morbidity and a reduced quality of life (QoL) (Sun et al., 2010). Many patients develop complications and musculoskeletal deficiencies, including graft versus host disease (GVHD), with devastating consequences on patient's QoL.

While there may exist an overlap in pathogenesis, clinical symptoms developed within 100 days post-HSCT (though this time frame is not a simple classifier) are classified as acute GVHD and can include signs of dermatitis (skin rash), cutaneous blisters, crampy abdominal pain with or without diarrhoea, persistent nausea and vomiting, and hepatitis (Jacobsohn and Vogelsang, 2007). On the other hand, cGVHD typically occurs 100 days after transplant, and the disease itself is not believed to be a continuation of acute GVHD. The condition is mainly an inflammatory and fibrotic process affecting the skin, fascia, muscles, bones, and joints, as well as other organs (Lee, 2005; Perez-Simon et al., 2006). However, to date, there does not exist a standard safe regimen for cGVHD treatment, and the majority of the drugs result in side effects with negative implications for patients' QoL (Perez-Simon et al., 2006). The National Health Service (NHS) in the UK has found that there is sufficient evidence to support a proposal for the routine commissioning of Extracorporeal photopheresis (ECP) for acute GVHD, and a combination of ECP, pentostatin, rituximab, and imatinib for cGVHD (National Health Service, 2017). However, these treatments can also have adverse effects, and some require extensive logistic support. 
Rehabilitation interventions are increasingly being seen as a major player in managing the musculoskeletal aspects of cGVHD due to the involvement of fascia, muscles, and bones, causing functional incapacity in patients (Hashmi et al., 2015; Dignan et al., 2013). A number of studies have demonstrated that rehabilitation interventions may be useful in reducing postHSCT musculoskeletal manifestations (Rosenthal et al., 2019; Chatterjee and De, 2017; Fiuza-Luces et al., 2016; Wiskemann et al., 2015; Braveman et al., 2017), However, anecdotal reports have suggested that these patients, in many cases, are only receiving rehabilitation services as a reactive approach to disease progression (Gajewski et al., 2009). Furthermore, the majority of patients do not accept long-term follow up from the rehabilitation team. The current paper not only outlines the various complications faced by this patient group from a QoL perspective, but also analyses the decisive role of rehabilitation and its importance as a long-term team factor in treatment.

\section{Impact of cGVHD on patients' QoL}

cGVHD occurs in up to $77 \%$ of patients' post allotransplant condition in the long term (Gale et al., 1987; Lee et al., 2003) and can affect several organs in the body, including the liver, gut, eyes, mouth, oesophagus, skin, fascia, lungs, and musculoskeletal system (Higman and Vogelsang, 2004; Baird and Pavletic, 2006). Furthermore, cGVHD is often coupled with comorbidities that require ongoing drug and other therapies, leading to further damage to the musculoskeletal system and resulting in a major impact on patients' QoL (Smith et al., 2015; Gielissen et al., 2007). Avascular necrosis of the bones, steroid myopathy, fatigue, fasciitis, scleroderma, neuropathy, joint destruction, cardiovascular compromise, osteopenia and osteoporosis, reduced lung capacity, reduced sexual capacity, vaginal or genital GVHD, and poor pelvic floor muscles may be part of the impact of cGVHD and related drug treatments in 
patients (Smith et al., 2015; Lee et al., 2006; Pereira and de Carvalho, 2011; Kovalszki et al., 2008). Many of these complications can develop gradually over time and last for as long as two years of transplant, such is the case for avascular necrosis of the femoral head (Atkinson et al., 1987). Functional incapacity in this patient group can be long-lasting and range from five to 20 years, having a considerable impact on a patient's daily activities, psychological well-being, and social life (Syrjala et al., 2011; Arora et al., 2016). This long-term instability in health also means that many patients are unable to return to work, resulting in a loss of income and subsequent financial hardship (Hamilton et al., 2018). Furthermore, the impact of cGVHD has been reported on multiple domains of QoL, including physical function, body pain, social function, emotional, mental health, sexual health, and psychological wellbeing (Pidala et al., 2011; Amonoo et al., 2019).

One of the major challenges faced by cGVHD patients is that expected positive outcomes of pharmacological intervention have, so far, been limited, offer with little or no benefit (Linhares et al., 2013). Therefore, non-pharmacological methods of improving QoL in these patients are being explored because physical exercises are beneficial not only post-HSCT, but also before the transplant (Liang et al., 2018). Therefore, the role of rehabilitation in managing cGVHD involves exercise intervention to improve functioning in daily living activities (ADL). However, there is a growing concern that the expertise of the allied healthcare team is not fully exploited by healthcare organisations (Bakhsh et al., 2018).

Although a number of studies have looked at the benefits of rehabilitation in HSCT and cGVHD, none have looked at justifying the need for long-term, ongoing rehabilitation for this patient group from a policymaker point of view; policymakers are responsible for providing or prioritising services based on dialogue and evidence (Elliott and Popay, 2000). Therefore, this review has two objectives. The first of these objectives is to inform healthcare policymakers and insurance companies of the importance of providing ongoing access to 
rehabilitation services for patients undergoing HSCT. The second objective is to analyse the current evidence of rehabilitation intervention in HSCT and cGVHD and highlight the need for further research.

\section{METHODS}

\section{Study team}

To attain findings that are clinically robust and relevant, the team for this study encompassed individuals with expertise in evidence synthesis, quantitative research methodology, occupational therapy, physiotherapy, and haematology and transplantation. A systematic literature research was employed to answer the research question: should healthcare organisations offer ongoing rehabilitation services for patients undergoing haematopoietic cell transplant? And in order to answer this question, a narrative review was conducted. The results were summarized narratively due to the range of studies included in the review.

\section{Search strategy and data sources}

A systematic search was completed in compliance with Preferred Reporting Items for Systematic Reviews and Meta-analysis (PRISMA) guideline (Moher et al., 2009). The Population Intervention Comparison Outcome (PICO) framework (Table 1) was used to ensure that the search strategies were structured and of high precision.

A systematic literature search was performed using the following databases: Health Research Premium Collection; SciTech Premium Collection; Biological Science Database; Natural Science Collection; ProQuest Central (new); ProQuest Hospital Collection; ProQuest Health \& Medical Complete; Medical Database; MEDLINE/PubMed (NLM); ProQuest Pharma Collection; OneFile (GALE); ProQuest Environmental Science Collection; Health Reference Centre Academic (Gale); and ProQuest Central Essentials from 1998 to 2018 to ensure that 
the review would cover a number of articles and because only a small number of clinical trials on physiotherapy have been undertaken over the past two decades. The review also involved manually searching the reference lists of all related articles and Google Scholar to determine relevant references. Boolean logic was used with the following terms, text word, and thesaurus to minimize chances of missing related articles: Hematopoietic Stem Cell Transplant; Chronic graft versus host disease; Rehabilitation; Exercise; Physical therapy; and Occupational therapy.

\section{Study selection and eligibility criteria}

The selection of included studies was completed over two stages. Initially, identified studies were independently screened for eligibility based on title and abstract by two independent reviewers (JM and RS); accordingly, results were compared for consistency. Secondly, the full texts of eligible studies were screened with the inclusion/exclusion criteria listed in Table 2 by the same independent reviewers. A third independent reviewer (HB) resolved disagreements.

\footnotetext{
$\rightarrow$ Insert Figure 1 here $\leftarrow$

$\rightarrow$ Insert Table 1 here $\leftarrow$

$\rightarrow$ Insert Table 2 here $\leftarrow$
} 


\section{Data Extraction, synthesis, and analysis}

The characteristics of the included studies are presented in Table 3. Studies were categorised by in-patient or out-patient, interventions, and qualitative or quantitative outcomes. The studies included in this narrative review were both quantitative and qualitative research studies. Therefore, a meta-analysis was not pursued due to the variations across studies, such as the statistical heterogeneity being too high, different interventions, different study designs and outcomes, and a lack of statistical findings.

\section{Insert Table 3 here $\leftarrow$}

Quality assessment

The Modified Jadad Quality scoring method was chosen to assess the quality of randomised control trial for the current narrative review (Table 4) (Jadad et al., 1996). The Jadad Quality scoring system demands randomization, masking, and accountability for all patients, including withdrawals against which the studies are scored. There are five questions which are answered as "yes" or "no". Each "yes" gives one point and each "no" means that a point is subtracted, as described by Schäfer et al. (Schäfer et al., 2016).

$\rightarrow$ Insert Table 4 here $\leftarrow$

\section{Study limitations}

The search was primarily limited to RCTs to capture and analyse high-quality trials in order to examine existing evidence informing on intervention and outcomes published in English. Therefore, the conclusions of this research are a reflection of a limited number of articles that 
were available in this language. Systematic reviews, meta-analysis and review papers were

\section{used for supporting the literature.}

Of the 19 included studies, only one was primarily pre-transplant intervention (Jacobsen et al., 2014), one was out-patient only (Persoon et al., 2017), nine were in-patient based, and nine were both in- and out-patient based. None of the studies considered continual rehabilitation exercise interventions to cover pre-transplant, in-patient, and out-patient treatment. Moreover, in the absence of the pre-transplant functional assessment by physical or occupational therapists, it is difficult to analyse the real outcomes of rehabilitation intervention programmes and whether patients were able to return to normal (pre-transplant functional capacity). Additionally, the included studies combined both adult and paediatric populations, with the majority of the studies having a small, heterogeneous sample, which may make it difficult to make strong recommendations. Finally, the lack of a specific grading system for RCTs in physical and occupational therapy is needed as most of the studies scored, which makes it apparent that the interventions as not as effective as is being described.

However, the findings of this review demonstrate that exercise intervention is safe for patients with malignancies pre-, during, and post-HSCT. Despite the variations in the exercise intervention, both strength and endurance exercises are well tolerated by patients and safe for patients undergoing an HSCT. Furthermore, the current review highlights not only the need for rehabilitation specific RCTs scoring system, but also the importance of future researchers investing in patient-specific exercise prescription that covers the entire duration of the transplant starting from pre-, during, and post-HSCT. 


\section{RESULTS}

\section{Identification of studies}

A PRISMA flowchart of the study identification process is presented in Figure 1. After removing duplicates, 1411 studies were identified as potential records, 51 studies underwent title/abstract screening for their appropriateness to the current review, 30 were reviewed in full, and 19 studies were ultimately included in the review. The current review focuses on analysing exercise interventions and reported outcomes during and post-HSCT, including patients with cGVHD, on various health-related parameters, as presented in Table 5.

$\rightarrow$ Insert Table 5 here $\leftarrow$

Data extraction, synthesis, and analysis

Out of the 19 studies included in this review, nine are in-patient based, eight are in outpatientbased, one pre-transplant and one outpatient specific. The included studies covered approximately 1,776 patients, aged between 5 and 73 years, both male and female from various ethnic backgrounds and from nine countries. The outcomes studied included not only strength and QoL, but also other parameters such as muscle endurance, fatigue, physical fitness, functional capacity, cardiorespiratory fitness, muscle mass, cytopenia, physiological function, psychological wellbeing, diarrhoea, immune cell recovery, psychosocial, anxiety, depression, and haemoglobin.

Although the majority of the studies $(n=16)$ have reported the positive impact of exercise interventions $(84 \%)$, three studies reported little or no benefit on patient's physical fitness, strength, endurance, and fatigue, including one pre-transplant study, one in-patient, and one out-patient study (16\%). In the trials reviewed, the following themes were identified:

Exercise prescription 
The science of exercise prescription is being underutilised in the majority of the studies, out of the 19 studies included in this review only three studies mentioned prescribing exercises as per individual patient capacity (Shelton et al., 2009; Yildiz Kabak et al., 2016; Persoon et al., 2017).

\section{Specialists involved in designing exercise protocols}

Interestingly the exercise prescription for the patients was not limited to the exercise physiologists or an experienced physical therapist but, other healthcare professionals also appeared to be designing exercises. We found nurse specialist, professors, doctors, registered nurse practitioners, and rheumatologists providing exercise prescriptions for the studies. Futhermore, several studies mentioned and discussued exercise physiologist being involved in exercise prescription (Persoon et al., 2017; Shelton et al., 2009; Baumann et al., 2011; Yildiz Kabak et al., 2016; Jarden et al., 2009; Schumacher et al., 2018; Morishita et al., 2013a; Takekiyo et al., 2015; Wood et al., 2016; Wiskemann et al., 2011).

The rationale behind the chosen exercises

Shelton et al., Kabak et al., and Persoon et al. were the only studies that described the rationale for choosing the set of exercises concerning outcome measures (Shelton et al., 2009; Yildiz Kabak et al., 2016; Persoon et al., 2017).

\section{No standardised exercise protocols}

Significant variation was found in the clinical trials in terms of the design of exercises in trails such as Jacobsen et al. (Jacobsen et al., 2014), who used only walking three to five times a week for at least 20 to 30 minutes at $50 \%$ to $75 \%$ estimated heart rate reserve as their intervention. On the other hand, Jarden et al. (Jarden et al., 2009) implemented a diverse 
exercise programme, which included cardiovascular training, core exercises, strength and endurance for upper and lower limbs. Each study followed a specific design in terms of the number of repetitions, sets, frequency, and intensity and was influenced by a set of cautions and contraindications but did not always include a scientific methodology aimed at achieving optimal muscle performance, tissue endurance, cardiovascular fitness, and functional capacity.

\section{Trial quality}

Of the 19 studies included in this review, only $10(53 \%)$ achieved a $2 / 5$ score with randomisation in trials and outlined the dropout rates; three studies achieved 1/5 (16\%) with randomisation in the trial but failed to mention dropouts from the trials, and six studies scored $-1 / 5(32 \%)$ as they did not mention randomisation or dropouts. Furthermore, none of the trials followed double-blinded approach due to the nature of the intervention.

\section{DISCUSSION}

The majority of patients develop some level of musculoskeletal and cardiovascular complications post-HCT (Armenian et al., 2017; Majhail et al., 2012; Mohammed et al., 2018a; Bar et al., 2020). Some patients may suffer from these complications for several decades, meaning that they have a significant impact on their health-related QoL. The current paper reiterates and highlights challenges faced by HSCT patients, ranging from functional incapacity to financial loss and psychological (Bieri et al., 2008; Morishita et al., 2013b; Bona et al., 2015), allowing informed decisions to be made by various stakeholders and policymakers responsible for rationing services for patients (Iacobucci, 2017).

Over the past several decades, rehabilitation intervention has been increasingly used, and recommended as beneficial in patients before, during, and after HSCT. The majority of the 
trials included in this review demonstrated the benefit of exercise interventions on various parameters, including strength, QoL, muscle endurance, fatigue, physical fitness, daily living activities, functional capacity, cardiorespiratory fitness, muscle mass, cytopenia, physiological function, psychological wellbeing, diarrhoea, immune cell recovery, psychosocial, anxiety, depression, and haemoglobin.

\section{The need for more effective exercise prescription practice}

Rehabilitation specialists should take into account the complex medical background of individual patients and treatment-related complications. The current review also highlighted the lack of standardisation in exercise prescription for rehabilitation trials in HSCT. Exercise prescription aimed at achieving optimal outcomes considers individual patient characteristics i.e. age, type of disease, previous and present treatments and their side effects, presence of specific symptoms such as GVHD, drug intake, and other physiological parameters (Hayes et al., 2009). HSCT patients are known to suffer from a diverse number of medical and musculoskeletal manifestations due to the nature of their disease and HSCT-related complications (Savani et al., 2011). These conditions can present a challenge if individual circumstances are not considered when designing an exercise plan.

Furthermore, exercises design follows a specific plan that is precise and aimed at positively influencing one's physiological/biological parameters (McDonnell et al., 2005; Lephart et al., 2007; Roach et al., 2011). For example, the Targeted Risk Reduction Intervention through Defined Exercise (STRRIDE) studied the effects of exercise training regimens differing in dose (kcal.wk-1) and/or intensity (relative to peak VO2) and found that the amount and intensity of exercise are key in achieving both general and specific health benefits (Kraus et al., 2001). Therefore, HSCT rehabilitation specialists had to develop future trials using 
models implementing the science of exercise prescription and individualised program to study the optimal benefits of exercise as an intervention. 


\section{The need for high-quality hybrid trials}

Although a number of studies have supported physical exercises and rehabilitation interventions for HSCT patients, the benefits seem to have been overshadowed by the level of the overall quality of trials. The issue surrounding the quality of trials is not new, with over $40 \%$ of rehabilitation trials being scored as poor (Armijo-Olivo et al., 2015). A significant emphasis on double-blinding by a majority of these scales has been attributed as one of the reasons for which rehabilitation trials score low in terms of quality (Armijo-Olivo et al., 2017). Unlike other areas of medical science research, double-blinding is almost impossible to achieve for the majority of rehabilitation interventions due to the nature of the treatment (Opara et al., 2013; Olivo et al., 2008). Therefore, "the lack of statistical significance between blinding and effect sizes should not be interpreted as meaning that an impact of blinding on effect size is not present in physical therapy" (Opara et al., 2013). Moreover, due to the diversity involved in the rehabilitation intervention and outcomes that are measured, other scales such as Cochrane scale have found to not be accurate in assessing the risk of bias as some trials have shown to have achieved different quality scores with the two different scales (Armijo-Olivo et al., 2015), highlighting the need for a more specific/hybrid grading system (Olivo et al., 2008; Armijo-Olivo et al., 2017)

\section{The need for innovation}

Electrotherapy modalities are widely used by rehabilitation specialists to enhance tissue healing and patients' overall recovery (Watson, 2000; Shah and Farrow, 2012). However, this literature review identified a significant gap in application and practice of electrotherapy modalities in managing a number of the common musculoskeletal manifestations related to post-HSCT, which may have otherwise been treated by electrotherapy as a standalone or as part of an exercise programme (Mohammed et al., 2018b). For example, osteonecrosis of the 
bones has been identified as a common complication in this patient group that results in reduced QoL and requires surgery in many cases (Atkinson et al., 1987). Extracorporeal shock wave therapy (ESWT) is a modality reported as beneficial for improving functional capacity, pain, or even slowing down or blocking the progression of disease, thereby reducing the need for surgery (Zhang et al., 2017). However, few highquality trials involving these modalities exist in the literature, meaning that it may be too early to recommend or standardise this procedure. Similarly, other modalities such as vibration training and electrical nerve stimulation for neuropathic pain, as well as muscle stimulation for muscle atrophy, may have been reported as beneficial, though their use in HSCT patients remains widely unexplored (Streckmann et al., 2019; Mokhtari et al., 2020; Gobbo et al., 2019).

\section{No adverse effects of exercise therapy}

Despite discrepancies in the quality of the trials, type of intervention, and methodology, none of the studies included in this review mentioned an adverse event as a direct result of rehabilitation exercise intervention. This finding is in line with other studies, where the children with severe thrombocytopenia undergoing HSCT were found to have only minor and relatively rare bleeding complications due to physical and occupational therapy interventions (Ibanez et al., 2018). Furthermore, the majority of the previous systematic reviews, despite eluding to the need for more robust clinical trials, have agreed that exercise is safe and has a positive impact on patients' physical function, HRQoL, and fatigue (Persoon et al., 2013; Van Haren et al., 2013; Kruijsen-Jaarsma et al., 2013; Oberoi et al., 2018). 


\section{CONCLUSION}

Based on the existing literature, it is evident that a large number of HCT patients develop transplant-related complications and require long-term follow-up from a multidisciplinary team that includes rehabilitation specialists. There is strong evidence base that long-term rehabilitation can help HCT patients gain their functional capacity, improve quality of life and help patients intergrate back to their social and work life. Furthermore, lack of long-term support can be detremental to HCT patients resulting in various complications and associated economic burden for managing them. The healthcare policy makers/managers need to rcognise this need and make special considerations when rationing services for HCT patients. Although rehabilitation interventions have been reported as having positive impact on the patients overall quality of life, high quality trials are urgently needed to better this claim. Furthermore, there appears to be a gap in the research in terms of the use of various electrotherapy modalities as standalone therapies or in combination with exercises for MSKrelated complications post-HCT. Therefore, high-quality trials are needed using innovate treatment ideas in this patient group. 


\section{References}

Amonoo HL, Barclay ME, El-Jawahri A, et al. (2019) Positive psychological constructs and health outcomes in hematopoietic stem cell transplantation patients: A systematic review. Biol Blood Marrow Transplant 25(1): e5-e16.

Armenian SH, Chemaitilly W, Chen M, et al. (2017) National Institutes of Health Hematopoietic Cell Transplantation Late Effects Initiative: The Cardiovascular Disease and Associated Risk Factors Working Group Report. Biology of Blood and Marrow Transplantation 23(2): 201-210.

Armijo-Olivo S, da Costa BR, Cummings GG, et al. (2015) PEDro or Cochrane to assess the quality of clinical trials? A meta-epidemiological study. PLoS One 10(7): e0132634.

Armijo-Olivo S, Fuentes J, da Costa BR, et al. (2017) Blinding in physical therapy trials and its association with treatment effects: a meta-epidemiological study. Am J Phys Med Rehab 96(1): 34-44.

Arora M, Sun C-L, Ness KK, et al. (2016) Physiologic frailty in nonelderly hematopoietic cell transplantation patients: results from the bone marrow transplant survivor study. JAMA oncology 2(10): 1277-1286.

Atkinson K, Cohen M and Biggs J (1987) Avascular necrosis of the femoral head secondary to corticosteroid therapy for graft-versus-host disease after marrow transplantation: effective therapy with hip arthroplasty. Bone Marrow Transplant 2(4): 421-426.

Baird K and Pavletic SZ (2006) Chronic graft versus host disease. Curr Opin in Hematol 13(6): 426435.

Bakhsh HR, Mohammed J and Hashmi SK (2018) Are graft-versus-host-disease patients missing out on the vital occupational therapy services? a systematic review. Int J Rehabil Res 41(2): 110113.

Bar M, Ott SM, Lewiecki EM, et al. (2020) Bone Health Management After Hematopoietic Cell Transplantation: An Expert Panel Opinion from the American Society for Transplantation and Cellular Therapy. Biology of Blood and Marrow Transplantation 26(10): 1784-1802.

Baumann FT, Zopf EM, Nykamp E, et al. (2011) Physical activity for patients undergoing an allogeneic hematopoietic stem cell transplantation: benefits of a moderate exercise intervention. Eur J Haematol 87(2): 148-156.

Bieri S, Roosnek E, Helg C, et al. (2008) Quality of life and social integration after allogeneic hematopoietic SCT. Bone Marrow Transplant 42(12): 819-827.

Bona K, London WB, Guo D, et al. (2015) Prevalence and impact of financial hardship among New England pediatric stem cell transplantation families. Biol Blood Marrow Transplant 21(2): 312318.

Braveman B, Hunter EG, Nicholson J, et al. (2017) Occupational therapy interventions for adults with cancer. Amer J Occup Ther 71(5): 7105395010p7105395011-7105395010p7105395015. 
Chatterjee M and De R (2017) Effectiveness of Physiotherapy in Hand Dysfunction of Leukemia Patients with Chronic Musculoskeletal Graft versus Host Disease Post Bone MarrowTransplant. International Journal of Medical and Health Sciences 11(1).

Copelan EA (2006) Hematopoietic stem-cell transplantation. N Engl J Med 354(17): 1813-1826.

Dignan F, Manwani R, Potter M, et al. (2013) A dedicated GvHD clinic may improve the quality of life for allogeneic stem cell transplant survivors. Clin Transplant 27(1): E1-E2.

Elliott H and Popay J (2000) How are policy makers using evidence? Models of research utilisation and local NHS policy making. J Epidemiol Community Health 54(6): 461-468.

Fiuza-Luces C, Simpson RJ, Ramírez M, et al. (2016) Physical function and quality of life in patients with chronic GvHD: a summary of preclinical and clinical studies and a call for exercise intervention trials in patients. Bone Marrow Transplant 51(1): 13.

Gajewski JL, LeMaistre CF, Silver SM, et al. (2009) Impending challenges in the hematopoietic stem cell transplantation physician workforce. Blood Marrow Transplant 15(12): 1493-1501.

Gale RP, Bortin MM, van Bekkum DW, et al. (1987) Risk factors for acute graft-versus-host disease. Bri J Haematol 67(4): 397-406.

Gielissen M, Schattenberg A, Verhagen C, et al. (2007) Experience of severe fatigue in long-term survivors of stem cell transplantation. Bone Marrow Transplant 39(10): 595.

Gobbo M, Lazzarini S, Vacchi L, et al. (2019) Exercise Combined with Electrotherapy Enhances Motor Function in an Adolescent with Spinal Muscular Atrophy Type III. Case reports in neurological medicine 2019.

Hamilton BK, Rybicki L, Arai S, et al. (2018) Association of socioeconomic status with chronic graftversus-host disease outcomes. Biol Blood Marrow Transplant 24(2): 393-399.

Hashmi S, Carpenter P, Khera N, et al. (2015) Lost in transition: the essential need for long-term follow-up clinic for blood and marrow transplantation survivors. Biol Blood Marrow Transplant 21(2): 225-232.

Hayes SC, Spence RR, Galvão DA, et al. (2009) Australian Association for Exercise and Sport Science position stand: optimising cancer outcomes through exercise. J Sci Med Sport 12(4): 428-434.

Higman MA and Vogelsang GB (2004) Chronic graft versus host disease. Bri J Haematology 125(4): 435-454.

Iacobucci G (2017) Pressure on NHS finances drives new wave of postcode rationing. British Medical Journal Publishing Group.

Ibanez K, Espiritu N, Souverain RL, et al. (2018) Safety and feasibility of rehabilitation interventions in children undergoing hematopoietic stem cell transplant with thrombocytopenia. Arch Phys Med Rehabil 99(2): 226-233. 
Jacobsen PB, Le-Rademacher J, Jim H, et al. (2014) Exercise and stress management training prior to hematopoietic cell transplantation: Blood and Marrow Transplant Clinical Trials Network (BMT CTN) 0902. Biol Blood Marrow Transplant 20(10): 1530-1536.

Jacobsohn DA and Vogelsang GB (2007) Acute graft versus host disease. Orphanet J Rare Dis 2(1): 35.

Jadad AR, Moore RA, Carroll D, et al. (1996) Assessing the quality of reports of randomized clinical trials: is blinding necessary? Control Clin Trials 17(1): 1-12.

Jarden M, Baadsgaard MT, Hovgaard D, et al. (2009) A randomized trial on the effect of a multimodal intervention on physical capacity, functional performance and quality of life in adult patients undergoing allogeneic SCT. Bone Marrow Transplant 43(9): 725.

Kovalszki A, Schumaker G, Klein A, et al. (2008) Reduced respiratory and skeletal muscle strength in survivors of sibling or unrelated donor hematopoietic stem cell transplantation. Bone Marrow Transplant 41(11): 965.

Kraus WE, Torgan CE, Duscha BD, et al. (2001) Studies of a targeted risk reduction intervention through defined exercise (STRRIDE). Med Sci Sport Exer 33(10): 1774-1784.

Kruijsen-Jaarsma M, Révész D, Bierings MB, et al. (2013) Effects of exercise on immune function in patients with cancer: a systematic review. Exerc Immunol Rev 19.

Lee HJ, Oran B, Saliba RM, et al. (2006) Steroid myopathy in patients with acute graft-versus-host disease treated with high-dose steroid therapy. Bone Marrow Transplant 38(4): 299-303.

Lee SJ (2005) New approaches for preventing and treating chronic graft-versus-host disease. Blood 105(11): 4200-4206.

Lee SJ, Vogelsang G and Flowers ME (2003) Chronic graft-versus-host disease. Biol Blood Marrow Transplant 9(4): 215-233.

Lephart SM, Smoliga JM, Myers JB, et al. (2007) An eight-week golf-specific exercise program improves physical characteristics, swing mechanics, and golf performance in recreational golfers. J Strength Cond Res 21(3): 860-869.

Liang Y, Zhou M, Wang F, et al. (2018) Exercise for physical fitness, fatigue and quality of life of patients undergoing hematopoietic stem cell transplantation: a meta-analysis of randomized controlled trials. Jpn J Clin Oncol 48(12): 1046-1057.

Linhares YPL, Pavletic S and Gale RP (2013) Chronic GVHD: Where are we? Where do we want to be? Will immunomodulatory drugs help? Bone Marrow Transplant 48(2): 203-209.

Majhail NS, Douglas Rizzo J, Lee SJ, et al. (2012) Recommended Screening and Preventive Practices for Long-Term Survivors after Hematopoietic Cell Transplantation. Hematology/Oncology and Stem Cell Therapy 5(1): 1-30.

McDonnell MK, Sahrmann SA and Van Dillen L (2005) A specific exercise program and modification of postural alignment for treatment of cervicogenic headache: a case report. $J$ Orthop Sport Phys 35(1): 3-15. 
Mohammed J, Akomolafe T, Aljurf M, et al. (2018a) 'To treat or not to treat': raising awareness on the effects of graft versus host disease drugs on musculoskeletal system. Bone Marrow Transplantation 53(7): 909-912.

Mohammed J, Savani B, El-Jawahri A, et al. (2018b) Is there any role for physical therapy in chronic GvHD? Bone Marrow Transplant 53(1): 22.

Moher D, Liberati A, Tetzlaff J, et al. (2009) Preferred reporting items for systematic reviews and meta-analyses: the PRISMA statement. BMJ 339: b2535.

Mokhtari T, Ren Q, Li N, et al. (2020) Transcutaneous electrical nerve stimulation in relieving neuropathic pain: Basic mechanisms and clinical applications. Curr Pain Headache R 24(4): 114.

Morishita S, Kaida K, Setogawa K, et al. (2013a) Safety and feasibility of physical therapy in cytopenic patients during allogeneic haematopoietic stem cell transplantation. Eur J Cancer Care 22(3): 289-299.

Morishita S, Kaida K, Yamauchi S, et al. (2013b) Gender differences in health-related quality of life, physical function and psychological status among patients in the early phase following allogeneic haematopoietic stem cell transplantation. Psychooncology 22(5): 1159-1166.

National Health Service (2017) Treatments for Graft versus Host Disease (GvHD) following Haematopoietic Stem Cell Transplantation. Available at: https://www.england.nhs.uk/publication/treatments-for-graft-versus-host-disease-gvhdfollowing-haematopoietic/ (accessed 24 Decemeber).

Oberoi S, Robinson PD, Cataudella D, et al. (2018) Physical activity reduces fatigue in patients with cancer and hematopoietic stem cell transplant recipients: a systematic review and meta-analysis of randomized trials. CRIT REV ONCOL HEMAT 122: 52-59.

Olivo SA, Macedo LG, Gadotti IC, et al. (2008) Scales to assess the quality of randomized controlled trials: a systematic review. Physical therapy 88(2): 156-175.

Opara J, Kucio C, Małecki A, et al. (2013) Methods of blinding clinical trials in physiotherapy. Physiotherapy 21(1): 62-64.

Pereira RMR and de Carvalho JF (2011) Glucocorticoid-induced myopathy. Joint Bone Spine 78(1): 41-44.

Perez-Simon JA, Sánchez-Abarca I, Díez-Campelo M, et al. (2006) Chronic graft-versus-host disease. Drugs 66(8): 1041-1057.

Persoon S, ChinAPaw MJ, Buffart LM, et al. (2017) Randomized controlled trial on the effects of a supervised high intensity exercise program in patients with a hematologic malignancy treated with autologous stem cell transplantation: Results from the EXIST study. PLoS One 12(7): $\mathrm{e} 0181313$. 
Persoon S, Kersten MJ, van der Weiden K, et al. (2013) Effects of exercise in patients treated with stem cell transplantation for a hematologic malignancy: a systematic review and meta-analysis. Cancer treatment reviews 39(6): 682-690.

Pidala J, Kurland B, Chai X, et al. (2011) Patient-reported quality of life is associated with severity of chronic graft-versus-host disease as measured by NIH criteria: report on baseline data from the Chronic GVHD Consortium. Blood, The Journal of the American Society of Hematology 117(17): 4651-4657.

Roach KE, Tappen RM, Kirk-Sanchez N, et al. (2011) A randomized controlled trial of an activity specific exercise program for individuals with Alzheimer disease in long-term care settings. Journal of geriatric physical therapy (2001) 34(2): 50.

Rosenthal E, Mitchell S, Pavletic S, et al. (2019) Occupational Participation and Quality of Life in Persons With Chronic Graft-Versus-Host Disease (cGVHD): An Exploratory Study. American Journal of Occupational Therapy 73(4_Supplement_1): 7311515287p7311515281$7311515287 \mathrm{p} 7311515281$.

Savani BN, Griffith ML, Jagasia S, et al. (2011) How I treat late effects in adults after allogeneic stem cell transplantation. Blood 117(11): 3002-3009.

Schäfer G, Valderramas S, Gomes A, et al. (2016) Physical exercise, pain and musculoskeletal function in patients with haemophilia: a systematic review. Haemophilia 22(3): e119-e129.

Schumacher H, Stüwe S, Kropp P, et al. (2018) A prospective, randomized evaluation of the feasibility of exergaming on patients undergoing hematopoietic stem cell transplantation. Bone marrow transplantation 53(5): 584.

Shah SGS and Farrow A (2012) Trends in the availability and usage of electrophysical agents in physiotherapy practices from 1990 to 2010: a review. Phys Ther Rev 17(4): 207-226.

Shelton ML, Lee JQ, Morris GS, et al. (2009) A randomized control trial of a supervised versus a self-directed exercise program for allogeneic stem cell transplant patients. Psycho-Oncology: Journal of the Psychological, Social and Behavioral Dimensions of Cancer 18(4): 353-359.

Smith SR, Haig AJ and Couriel DR (2015) Musculoskeletal, neurologic, and cardiopulmonary aspects of physical rehabilitation in patients with chronic graft-versus-host disease. Biology of Blood and Marrow Transplantation 21(5): 799-808.

Streckmann F, Lehmann H, Balke M, et al. (2019) Sensorimotor training and whole-body vibration training have the potential to reduce motor and sensory symptoms of chemotherapy-induced peripheral neuropathy—a randomized controlled pilot trial. Support. Care Cancer 27(7): 24712478.

Sun CL, Francisco L, Kawashima T, et al. (2010) Prevalence and predictors of chronic health conditions after hematopoietic cell transplantation: a report from the Bone Marrow Transplant Survivor Study. Blood 116(17): 3129-3139. 
Syrjala KL, Artherholt SB, Kurland BF, et al. (2011) Prospective neurocognitive function over 5 years after allogeneic hematopoietic cell transplantation for cancer survivors compared with matched controls at 5 years. Journal of clinical oncology 29(17): 2397.

Takekiyo T, Dozono K, Mitsuishi T, et al. (2015) Effect of exercise therapy on muscle mass and physical functioning in patients undergoing allogeneic hematopoietic stem cell transplantation. Supportive Care in Cancer 23(4): 985-992.

Van Haren IE, Timmerman H, Potting CM, et al. (2013) Physical exercise for patients undergoing hematopoietic stem cell transplantation: systematic review and meta-analyses of randomized controlled trials. Physical therapy 93(4): 514-528.

Watson T (2000) The role of electrotherapy in contemporary physiotherapy practice. Manual therapy 5(3): 132-141.

Wingard JR, Majhail NS, Brazauskas R, et al. (2011) Long-term survival and late deaths after allogeneic hematopoietic cell transplantation. Journal of clinical oncology 29(16): 2230.

Wiskemann J, Dreger P, Schwerdtfeger R, et al. (2011) Effects of a partly self-administered exercise program before, during, and after allogeneic stem cell transplantation. Blood 117(9): 26042613.

Wiskemann J, Kuehl R, Dreger P, et al. (2015) Physical Exercise Training versus Relaxation in Allogeneic stem cell transplantation (PETRA Study)-Rationale and design of a randomized trial to evaluate a yearlong exercise intervention on overall survival and side-effects after allogeneic stem cell transplantation. BMC cancer 15(1): 619.

Wood WA, Phillips B, Smith-Ryan AE, et al. (2016) Personalized home-based interval exercise training may improve cardiorespiratory fitness in cancer patients preparing to undergo hematopoietic cell transplantation. Bone marrow transplantation 51(7): 967.

Yildiz Kabak V, Duger T and Uckan Cetinkaya D (2016) Investigation of the effects of an exercise program on physical functions and activities of daily life in pediatric hematopoietic stem cell transplantation. Pediatric blood \& cancer 63(9): 1643-1648.

Zhang Q, Liu L, Sun W, et al. (2017) Extracorporeal shockwave therapy in osteonecrosis of femoral head: a systematic review of now available clinical evidences. Medicine 96(4). 
Fig.1 PRISMA Schematic presentation
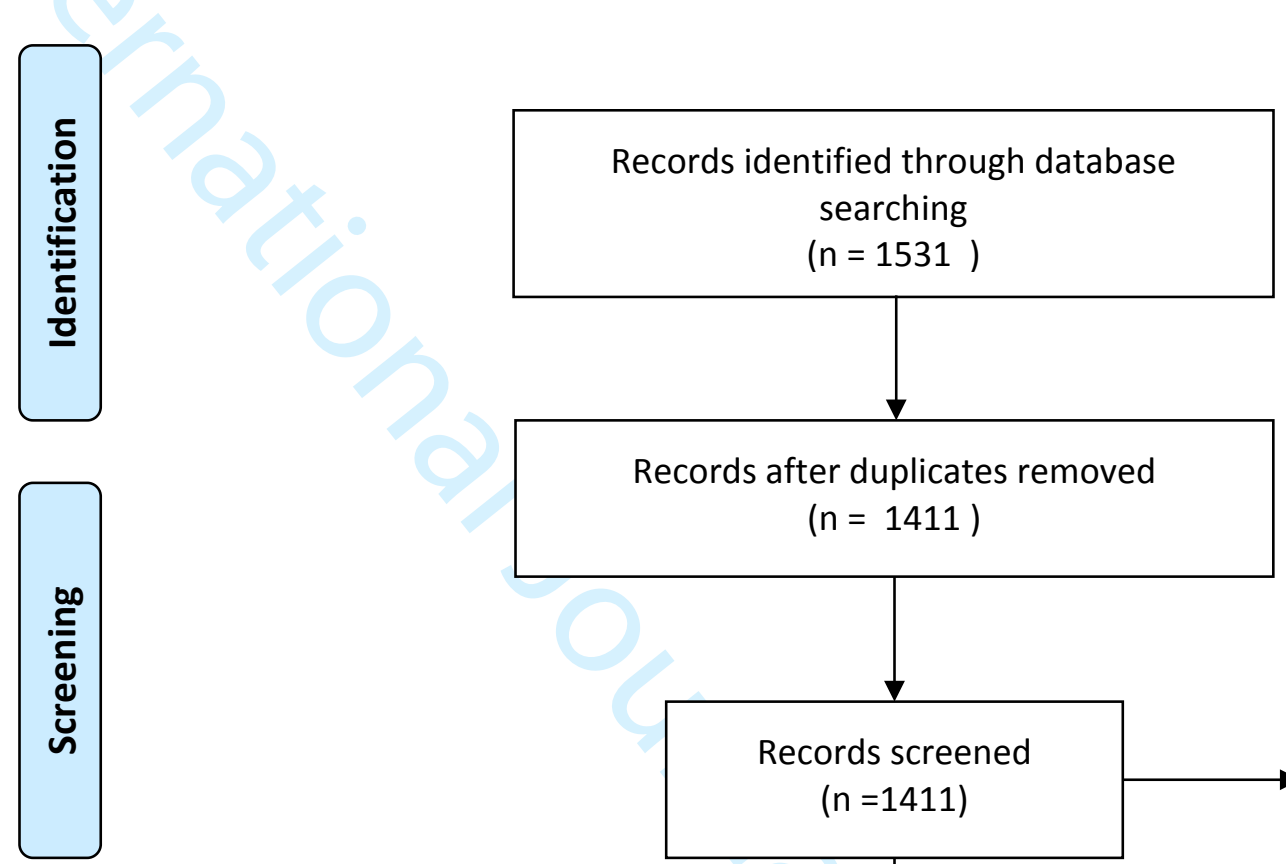

$$
(n=1411)
$$
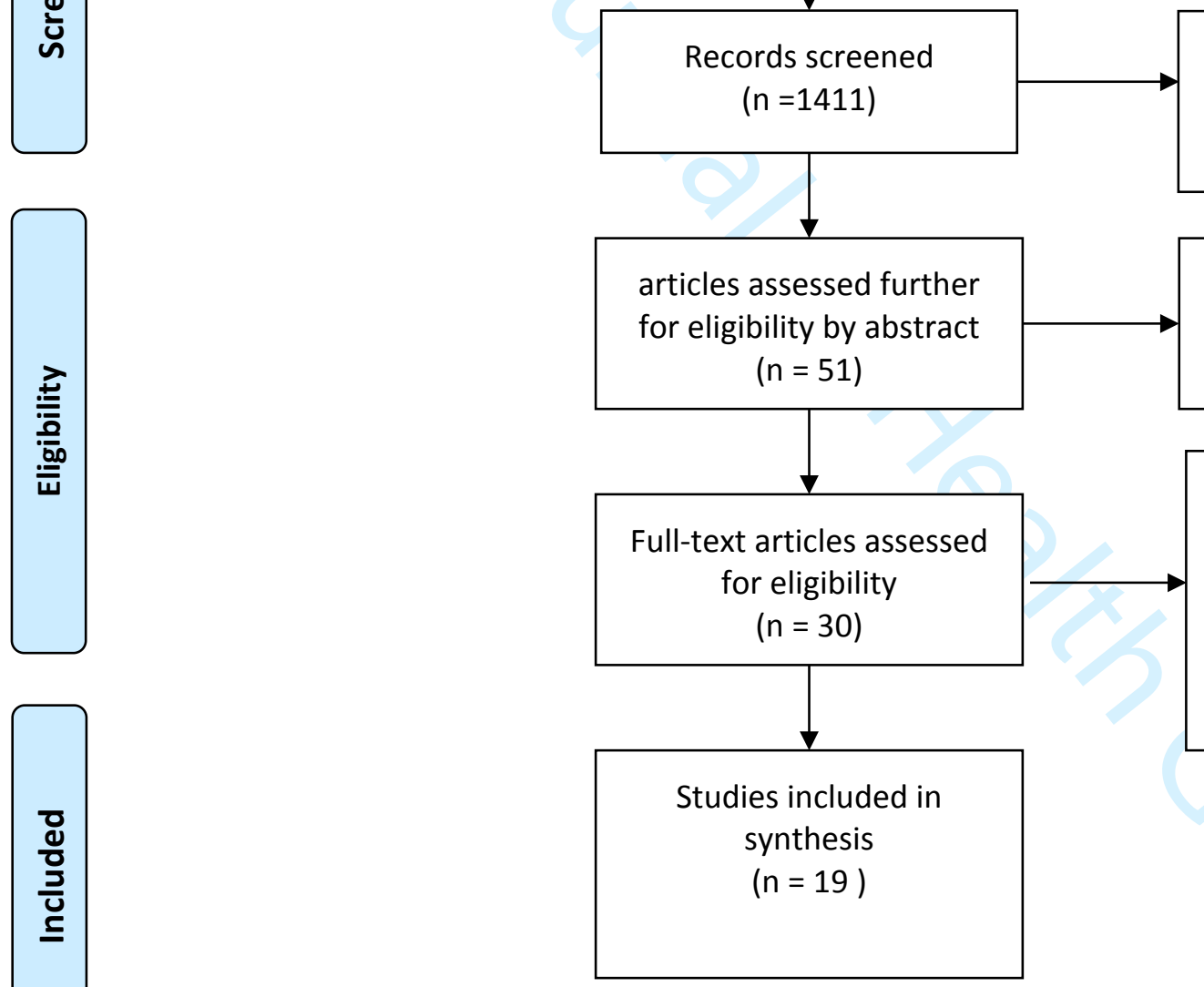

Records excluded (not relevant) $(n=1360)$

articles excluded (not relevant) $(n=21)$

Full-text articles excluded $(n=11)$

Not related to HSCT $n=2$

Animal studies $n=3$

Case study $n=3$

Full text unavailable $n=2$ 
Table.1 PICO: Rehabilitation intervention in cGVHD and its outcome

\begin{tabular}{|c|c|c|}
\hline Parameter & Evaluation & Explanation \\
\hline Population & $\begin{array}{l}\text { Male and female patients pre and post Hematopoietic } \\
\text { "Stem Cell Transplant" OR "Bone Marrow Transplant" } \\
\text { OR "hematopoietic cell transplant" with or without } \\
\text { GVHD. }\end{array}$ & $\begin{array}{l}\text { Both autologous and allogeneic } \\
\text { transplant patients will be } \\
\text { included. }\end{array}$ \\
\hline Intervention & $\begin{array}{l}\text { Rehabilitation exercises, cardiovascular and muscle } \\
\text { training intervention and any other physical or } \\
\text { occupational treatment are being evaluated. } \\
\text { Clinical trials, case reports, observational studies } \\
\text { (includes all types of retrospective studies), case-control } \\
\text { studies, }\end{array}$ & $\begin{array}{l}\text { Systematic reviews, review articles } \\
\text { and meta-analyses will be excluded } \\
\text { from the final data collection. } \\
\text { Preclinical studies will be } \\
\text { excluded. }\end{array}$ \\
\hline Comparison & $\begin{array}{l}\text { Comparison of various rehabilitation treatments and } \\
\text { their outcomes }\end{array}$ & $\begin{array}{l}\text { E.g. exercises specifically designed } \\
\text { as per individual patient capability } \\
\text { and medical condition versus } \\
\text { generalized exercises. }\end{array}$ \\
\hline Outcomes & $\begin{array}{l}\text { 1) Physical function } \\
\text { 2) ADL } \\
\text { 3) Muscle Strength } \\
\text { 4) Cardiovascular fitness }\end{array}$ & $\begin{array}{l}\text { And others which will be found via } \\
\text { search }\end{array}$ \\
\hline
\end{tabular}




\section{Table.2 Inclusion and exclusion criteria}

\begin{tabular}{|c|c|c|}
\hline 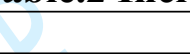 & Inclusion & Exclusion \\
\hline $\begin{array}{l}\text { Type } \\
\text { study }\end{array}$ & $\begin{array}{l}\text { All studies in English language only. } \\
\text { Randomised control trials with randomisation either at } \\
\text { the individual or cluster level } \\
\text { Quasi-randomised design } \\
\text { Duration: } 1998 \text { - } 2018 \\
\text { Retrospective }\end{array}$ & $\begin{array}{l}\text { Case reports (will be excluded for } \\
\text { data synthesis) } \\
\text { Systematic reviews } \\
\text { Meta-analysis } \\
\text { Preclinical studies } \\
\text { Studies reported as only abstracts }\end{array}$ \\
\hline Population & All HSCT patients and chronic GVHD patients. & Auto-transplant patients \\
\hline Intervention & $\begin{array}{l}\text { Exercise } \\
\text { Electrotherapy } \\
\text { Physiotherapy }\end{array}$ & \\
\hline Outcome & $\begin{array}{l}\text { Activities of daily life } \\
\text { Muscle power and endurance }\end{array}$ & Return to work \\
\hline
\end{tabular}


Table. 3 Type of study, intervention used, Outcome measures and if the treatment was in or outpatient

\begin{tabular}{|c|c|c|c|c|c|c|c|}
\hline Author \& Country & Year & Type of Study & Participants demographics & Intervention & Objective outcome measure & $\begin{array}{l}\text { Subjective outcome } \\
\text { measure }\end{array}$ & Setting \\
\hline $\begin{array}{l}\text { Mello, Tanaka and } \\
\text { Dulley } \\
\text { Brazil }\end{array}$ & 2003 & $\begin{array}{l}\text { Prospective cohort } \\
\text { study }\end{array}$ & $\begin{array}{l}\mathrm{C}=9 \quad(\mathrm{M}: 3, \text { Avg y: } 30.2) \\
\mathrm{I}=9 \quad(\mathrm{M}: 5, \text { Avg y: } 27.9) \\
\mathrm{ID}=6 \text { weeks }\end{array}$ & $\begin{array}{l}\text { active exercises, muscle } \\
\text { stretching and a walking-based } \\
\text { program on a treadmill }\end{array}$ & $\begin{array}{l}\text { Maximal isometric voluntary strength tests } \\
\text { (MIVS) from four muscle groups of the } \\
\text { upper limbs and five muscle groups of the } \\
\text { lower limbs were collected to assess the } \\
\text { subject's muscle strength }\end{array}$ & NIL & $\begin{array}{l}\text { In-Patient } \\
\text { and Out- } \\
\text { Patient }\end{array}$ \\
\hline $\begin{array}{l}\text { Kim \& Kim } \\
\text { South Korea }\end{array}$ & 2005 & RCT & $\begin{array}{l}\mathrm{C}=17(\mathrm{M}: 9, \text { Avg y: } 34.3) \\
\mathrm{I}=18(\mathrm{M}: 8, \text { Avg y: } 32.9) \\
\mathrm{ID}=6 \text { weeks }\end{array}$ & Relaxation Breathing Exercise & leukocyte count & $\begin{array}{l}\text { Beck Depression } \\
\text { Inventory } \\
\text { (BDI) }\end{array}$ & In-Patient \\
\hline $\begin{array}{l}\text { Coleman et al } \\
\text { USA }\end{array}$ & 2008 & $\mathrm{RCT}$ & $\begin{array}{l}\mathrm{C}=62(\mathrm{M}: 35, \text { Avg y: } 55) \\
\mathrm{I}=58 \text { (M: } 35, \text { Avg y: } 55) \\
\mathrm{ID}=15 \text { weeks }\end{array}$ & $\begin{array}{l}\text { individualized exercise } \\
\text { prescription }\end{array}$ & six-minute walk test & Borg Scale & In-Patient \\
\hline $\begin{array}{l}\text { Jarden et al } \\
\text { Denmark }\end{array}$ & 2009 & RCT & $\begin{array}{l}\mathrm{C}=21(\mathrm{M}: 13, \operatorname{Avg} \text { y: } 37.4) \\
\mathrm{I}=21 \quad(\mathrm{M}: 31, \operatorname{Avg} \mathrm{y}: 40.9) \\
\mathrm{ID}=\text { Not clear }\end{array}$ & $\begin{array}{l}\text { Dynamic and } \\
\text { stretching exercises Resistance } \\
\text { training Progressive relaxation }\end{array}$ & $\begin{array}{l}\text { Aastrand-Rhyming cycle ergometer test, } \\
\text { 1RM tests, maximal } \\
\text { isometric strength, 2-min stair climb test, }\end{array}$ & $\begin{array}{l}\text { EORTC } \\
\text { QLQ-C30, FACT-An, } \\
\text { Hospital Anxiety } \\
\text { and Depression Scale } \\
\text { (HADS) }\end{array}$ & In-Patient \\
\hline $\begin{array}{l}\text { Shelton et al } \\
\text { USA }\end{array}$ & 2009 & $\mathrm{RCT}$ & $\begin{array}{l}\mathrm{C}=27 \text { (M:16, Avg y: 48.9) } \\
\mathrm{I}=26 \text { (M:17, Avg y: 43.6) } \\
\mathrm{ID}=4 \text { weeks }\end{array}$ & Aerobic and strength exercises & $\begin{array}{l}\text { 50-foot fast walk, 6-min walk, forward } \\
\text { reach, repeated sit-to-stand, uniped stance) }\end{array}$ & $\begin{array}{l}\text { Brief Fatigue } \\
\text { Inventory (BFI) }\end{array}$ & In-Patient \\
\hline $\begin{array}{l}\text { Chamorro-vin et al } \\
\text { Spain }\end{array}$ & 2010 & $\begin{array}{c}\text { a controlled trial } \\
\text { using a } \\
\text { "historical", } \\
\text { control group } \\
\end{array}$ & $\begin{array}{l}\mathrm{C}=13 \text { (B: } 9, \text { Avg y: } 7.30) \\
\mathrm{I}=7 \quad \text { (B: } 5, \text { Avg y: } 8.14) \\
\mathrm{ID}=3 \text { weeks }\end{array}$ & $\begin{array}{l}\text { individually } \\
\text { supervised exercise program } \\
\text { including strength and } \\
\text { cardiovascular training }\end{array}$ & $\begin{array}{l}\text { Anthropometric variables, white blood cell } \\
\text { population counts }\end{array}$ & None & In-Patient \\
\hline $\begin{array}{l}\text { Baumann et al } \\
\text { Germany }\end{array}$ & 2011 & $\mathrm{RCT}$ & $\begin{array}{l}\mathrm{C}=16(\mathrm{M}: 5, \operatorname{Avg} \mathrm{y}: 42.81) \\
\mathrm{I}=17 \text { (M: } 11, \text { Avg y: } 41.41) \\
\mathrm{ID}=\text { Not clear }\end{array}$ & $\begin{array}{l}\text { aerobic endurance training and } \\
\text { 'ADL-training', gymnastics, } \\
\text { massages }\end{array}$ & $\begin{array}{l}\text { WHO-endurance test cycle ergometer, Lung } \\
\text { function vital capacity, forced vital capacity, } \\
\text { Strength Digimax } 2000 \text { - load cell }\end{array}$ & EORTC QLQ-C30 & In-Patient \\
\hline $\begin{array}{l}\text { Wiskemann et al } \\
\text { Germany }\end{array}$ & 2011 & $\mathrm{RCT}$ & $\begin{array}{l}\mathrm{C}=40(\mathrm{M}: 39, \operatorname{Avg} \mathrm{y}: 50) \\
\mathrm{I}=40 \quad(\mathrm{M}: 32, \operatorname{Avg} \mathrm{y}: 47.6) \\
\mathrm{ID}=6 \text { to } 8 \text { weeks }\end{array}$ & Aerobic and strength training & 6MWT, maximum of voluntary strength, & $\begin{array}{l}\text { Multidimensional } \\
\text { Fatigue Inventory } \\
\text { (MFI), EORTC QLQ- } \\
\text { C30, Borg Scale, } \\
\text { National } \\
\text { Comprehensive } \\
\text { Cancer Network } \\
\text { Distress- } \\
\text { Thermometer }\end{array}$ & $\begin{array}{l}\text { In-Patient } \\
\text { and Out- } \\
\text { Patient }\end{array}$ \\
\hline $\begin{array}{l}\text { Knols et al } \\
\text { Germany }\end{array}$ & 2011 & $\mathrm{RCT}$ & $\begin{array}{l}\mathrm{C}=64 \text { (M:39, Avg y: 46.6) } \\
\mathrm{I}=67 \text { (M:38, Avg y: 46.7) } \\
\mathrm{ID}=3 \text { months }\end{array}$ & $\begin{array}{l}\text { Supervised personal exercise } \\
\text { program including strength and } \\
\text { cardiovascular }\end{array}$ & $\begin{array}{l}\text { Maximum voluntary peak force in } \mathrm{Nm} \text {, } \\
\text { JAMAR dynamometer, } 50 \text {-foot walk test, } 6 \\
\text { min walk test, body composition }\end{array}$ & $\begin{array}{l}\text { Health-Related } \\
\text { Quality of Life } \\
\text { (HRQOL), FACT An, } \\
\text { EORTC QLQ-C30 }\end{array}$ & Out-Patient \\
\hline
\end{tabular}




\begin{tabular}{|c|c|c|c|c|c|c|c|}
\hline $\begin{array}{l}\text { Tran et al } \\
\text { USA }\end{array}$ & 2012 & $\begin{array}{c}\text { Retrospective } \\
\text { study }\end{array}$ & $\begin{array}{l}\mathrm{C}=0 \\
\mathrm{I}=11(\mathrm{M}: 8, \operatorname{Avg} \mathrm{y}: 48) \\
\mathrm{ID}=8 \text { weeks }\end{array}$ & $\begin{array}{l}\text { nutrition, medication and oxygen } \\
\text { safety, pursed-lip breathing and } \\
\text { other breathing techniques, use } \\
\text { and care of metered dose inhaler. } \\
\text { Upper and lower body strength } \\
\text { training and cardiovascular } \\
\text { exercise }\end{array}$ & $\begin{array}{l}\text { spirometry/pulmonary function tests, } 6 \text { - } \\
\text { minute walk tests. }\end{array}$ & SF-36 & $\begin{array}{l}\text { In-Patient } \\
\text { and Out- } \\
\text { Patient }\end{array}$ \\
\hline $\begin{array}{l}\text { Morishita et al } \\
\text { Japan }\end{array}$ & 2013 & $\begin{array}{l}\text { Observational, } \\
\text { longitudinal study }\end{array}$ & $\begin{array}{l}\mathrm{C}=51(\mathrm{M}: 47, \text { Avg y: } 41.6) \\
\mathrm{I}=51(\mathrm{M}: 137, \text { Avg y: } 45.2) \\
\mathrm{ID}=4 \text { weeks }\end{array}$ & $\begin{array}{l}\text { stretching exercises, resistance } \\
\text { training and } \\
\text { endurance training }\end{array}$ & $\begin{array}{l}\text { BMI, Hand Grip Measure, Handheld } \\
\text { dynamometer for Lower limb, 6min walk } \\
\text { test }\end{array}$ & SF 36 & In-Patient \\
\hline $\begin{array}{l}\text { Wiskemann et al } \\
\text { Germany }\end{array}$ & 2014 & RCT & $\begin{array}{l}\mathrm{C}=53(\mathrm{M}: 39, \operatorname{Avg} \mathrm{y}: 50) \\
\mathrm{I}=52(\mathrm{M}: 32, \operatorname{Avg} \mathrm{y}: 47.2) \\
\mathrm{ID}=8 \text { weeks }\end{array}$ & $\begin{array}{l}\text { endurance and resistance } \\
\text { exercises using stretch bands }\end{array}$ & 6-min walk test, & BORG Scale & $\begin{array}{l}\text { In-Patient } \\
\text { and Out- } \\
\text { Patient }\end{array}$ \\
\hline $\begin{array}{l}\text { Jacobsen et al } \\
\text { USA }\end{array}$ & 2014 & $\begin{array}{l}\mathrm{RCT} \text { (phase III } \\
\text { multicentre) }\end{array}$ & $\begin{array}{l}\text { Usual care = } 175 \text { (M:93, Avg y: 55) } \\
\text { Exercise }=180 \text { (M:112, Avg y: 58) } \\
\text { Stress management= } 178 \text { (M:100, } \\
\text { Avg y: } 58) \\
\text { Combination of exercise/stress } \\
\text { management= } 178 \text { (M:100, Avg y: } \\
\text { 57) } \\
\text { ID = } 180 \text { days }\end{array}$ & $\begin{array}{l}\text { walking } 3 \text { to } 5 \text { times a week for at } \\
\text { least } 20 \text { to } \\
30 \text { minutes at } 50 \% \text { to } 75 \% \text { of } \\
\text { estimated heart rate reserve }\end{array}$ & NIL & $\begin{array}{l}\text { SF-36, Cancer and } \\
\text { Treatment } \\
\text { Distress (CTXD), } \\
\text { Pittsburgh } \\
\text { Sleep Quality Index } \\
\text { (PSQI), Leisure Score } \\
\text { Index } \\
\text { (LSI) of the Godin } \\
\text { Leisure-Time Exercise } \\
\text { Questionnaire } \\
\end{array}$ & $\begin{array}{l}\text { Pre- } \\
\text { Transplant }\end{array}$ \\
\hline $\begin{array}{l}\text { Takekiyo et al } \\
\text { Japan }\end{array}$ & 2015 & $\begin{array}{l}\text { Prospective cohort } \\
\text { study }\end{array}$ & $\begin{array}{l}\mathrm{C}=18(\mathrm{M}: 11, \text { Avg y: } 54) \\
\mathrm{I}=17 \quad(\mathrm{M}: 12, \text { Avg y: } 55) \\
\mathrm{ID}=6 \text { weeks }\end{array}$ & high- and low-frequency exercise & $\begin{array}{l}\text { Body composition, 6-min walk } \\
\text { test (6MWT) scores, and handgrip strength }\end{array}$ & None & $\begin{array}{l}\text { In-Patient } \\
\text { and Out- } \\
\text { Patient }\end{array}$ \\
\hline $\begin{array}{l}\text { Kabak et } a l^{*} \\
\text { Turkey }\end{array}$ & 2016 & $\begin{array}{l}\text { prospective cohort } \\
\text { study }\end{array}$ & $\begin{array}{l}\mathrm{C}=11(\text { Avg y: } 6.72) \\
\mathrm{I}=11 \quad(\text { Avg y: } 9.3) \\
\mathrm{ID}=5 \text { to } 6 \text { weeks }\end{array}$ & $\begin{array}{l}\text { strengthening, endurance, } \\
\text { stretching, and relaxation } \\
\text { exercises }\end{array}$ & $\begin{array}{l}\text { 6-min walk test (6MWT), Handgrip strength, } \\
30 \text {-sec chair-stand test, Time needed to stand } \\
\text { up from bed rest exam, Time up and go } \\
\text { (TUG) test of } 3 \mathrm{~m} \text {, Timed up and down stairs } \\
\text { (TUDS) test }\end{array}$ & $\begin{array}{l}\text { Functional } \\
\text { independent measure } \\
\text { for children } \\
\text { (WeeFIM). } \\
\text { WeeFIM }\end{array}$ & $\begin{array}{l}\text { In-Patient } \\
\text { and Out- } \\
\text { Patient }\end{array}$ \\
\hline $\begin{array}{l}\text { Wood et al } \\
\text { USA }\end{array}$ & 2016 & $\begin{array}{l}\text { prospective cohort } \\
\text { study }\end{array}$ & $\begin{array}{l}\mathrm{C}=0 \\
\mathrm{I}=\mathrm{A} 20 \text { (M: } 14, \text { Avg y: } 60.5) \\
\text { B } 20 \text { (M: } 12 \text {, Avg y: } 52.5) \\
\text { ID }=6 \text { weeks }\end{array}$ & Interval exercise training & $\begin{array}{l}\text { maximal cardiopulmonary } \\
\text { exercise testing with cycle ergometry } \\
\text { (VO2peak), 6-minute walk distance, }\end{array}$ & None & $\begin{array}{l}\text { In-Patient } \\
\text { and Out- } \\
\text { Patient }\end{array}$ \\
\hline $\begin{array}{l}\text { Hacker et al } \\
\text { USA }\end{array}$ & 2017 & $\begin{array}{l}\text { Single blind } \\
\text { RCT }\end{array}$ & $\begin{array}{l}\mathrm{C}=34 \text { (M: } 21, \text { Avg y: } 54.6) \\
\mathrm{I}=33 \text { (M: } 20 \text {, Avg y: } 51.9) \\
\mathrm{ID}=6 \text { weeks }\end{array}$ & $\begin{array}{l}\text { progressive resistance to } \\
\text { strengthen the upper body, lower } \\
\text { body, and abdominal muscles } \\
\text { using elastic resistance bands }\end{array}$ & $\begin{array}{l}\text { Accelerometer, 6-minute walk test, } \\
\text { ultrasonic measurement } \\
\text { of the cross-sectional area of the rectus } \\
\text { femoris, hand grip strength, } \\
\text { and arm curl test. timed stair climb, } \\
\text { the timed up and go test, } 15 \text {-foot walk time, } \\
\text { and } 30 \text {-second chair-stand test. }\end{array}$ & $\begin{array}{l}\text { Godin leisure-time } \\
\text { exercise questionnaire, } \\
\text { Chalder fatigue scale, } \\
\text { EORTC QLQ-C30, }\end{array}$ & $\begin{array}{l}\text { In-Patient } \\
\text { and Out- } \\
\text { Patient }\end{array}$ \\
\hline
\end{tabular}




\begin{tabular}{|c|c|c|c|c|c|c|c|}
\hline $\begin{array}{l}\text { Persoon, et al } \\
\text { Netherlands }\end{array}$ & 2017 & single-blind RCT & $\begin{array}{l}\mathrm{C}=55(\mathrm{M}: 37, \operatorname{Avg} \mathrm{y}: 56) \\
\mathrm{I}=54(\mathrm{M}: 32, \text { Avg y: } 53.5) \\
\mathrm{ID}=18 \text { weeks }\end{array}$ & $\begin{array}{l}\text { high-intensity resistance exercise } \\
\text { and interval training program, } \\
\text { counselling service for motivation }\end{array}$ & $\begin{array}{l}\text { cardiopulmonary exercise } \\
\text { test, performed on a cycle ergometer, Grip } \\
\text { strength, BMI, accelerometers }\end{array}$ & $\begin{array}{l}\text { Multidimensional } \\
\text { Fatigue Inventory } \\
\text { (MFI), ORTC-QLQ- } \\
\text { C30, HADS }\end{array}$ & Out-Patient \\
\hline $\begin{array}{l}\text { Schumacher et al } \\
\text { Germany }\end{array}$ & 2018 & RCT & $\begin{array}{l}\mathrm{C}=23(\mathrm{M}: 9, \text { Avg y: } 56.5) \\
\mathrm{I}=19(\mathrm{M}: 16, \text { Avg y: } 56) \\
\mathrm{ID}=\text { not clear }\end{array}$ & $\begin{array}{l}\text { Stretching, strength training, } \\
\text { endurance and exercising on the } \\
\text { Nintendo Wii }\end{array}$ & $\begin{array}{l}2 \text { min walking distance test ( } 2 \mathrm{MWT}) \text {, } \\
\text { isometric grip strength, }\end{array}$ & $\begin{array}{l}\text { FACT-BMT, SF-36, } \\
\text { HADS-D, distress } \\
\text { thermometer }\end{array}$ & In-Patient \\
\hline
\end{tabular}

Abbreviations $\mathrm{C}=$ in control group; I=intervention group; ID=Intervention duration; M=Male; B=Boy; Avg y= Average age; RCT= Randomized Control Trial

*Participants demographics not reported 
Table 4. JADAD scoring of selected studies.

\begin{tabular}{|c|c|c|c|c|c|c|c|}
\hline Author & Year & $\begin{array}{c}\text { Was the } \\
\text { study } \\
\text { described as } \\
\text { Yes } \\
\text { randomized? }\end{array}$ & $\begin{array}{c}\text { randomization } \\
\text { scheme } \\
\text { described and } \\
\text { appropriate? }\end{array}$ & $\begin{array}{c}\text { Was the } \\
\text { study } \\
\text { described as } \\
\text { double } \\
\text { blinding? }\end{array}$ & $\begin{array}{c}\text { Was the } \\
\text { method of } \\
\text { blinding } \\
\text { appropriate? }\end{array}$ & $\begin{array}{c}\text { Was there a } \\
\text { description } \\
\text { of dropouts } \\
\text { and } \\
\text { withdrawals }\end{array}$ & $\begin{array}{c}\text { JADAD } \\
\text { Score }\end{array}$ \\
\hline $\begin{array}{c}\text { Mello, Tanaka } \\
\text { and Dulley }\end{array}$ & 2003 & +1 & +1 & 0 & -1 & -1 & 1 \\
\hline Kim \& Kim & 2005 & +1 & +1 & 0 & -1 & -1 & 1 \\
\hline Coleman et al & 2008 & +1 & +1 & 0 & -1 & +1 & 2 \\
\hline Jarden et al & 2009 & +1 & +1 & 0 & -1 & +1 & 2 \\
\hline Shelton et al & 2009 & +1 & +1 & 0 & -1 & $1+$ & 2 \\
\hline $\begin{array}{c}\text { Chamorro-vin } \text { et } \\
\text { al }\end{array}$ & 2010 & +1 & +1 & 0 & -1 & +1 & 2 \\
\hline Baumann et al & 2011 & +1 & +1 & 0 & -1 & +1 & 2 \\
\hline Knols et al & 2011 & -1 & -1 & 0 & -1 & +1 & -1 \\
\hline Wiskemann et al & 2011 & +1 & +1 & 0 & -1 & +1 & 2 \\
\hline Tran et al & 2012 & -1 & -1 & 0 & -1 & +1 & -1 \\
\hline Morishita et al & 2013 & -1 & -1 & 0 & -1 & +1 & -1 \\
\hline Jacobsen et al & 2014 & +1 & +1 & 0 & -1 & +1 & 2 \\
\hline Wiskmann et al & 2014 & +1 & +1 & 0 & -1 & +1 & 2 \\
\hline Takekiyo et al & 2015 & -1 & -1 & 0 & -1 & +1 & -1 \\
\hline Kabak et al & 2016 & -1 & -1 & 0 & -1 & +1 & -1 \\
\hline Wood et al & 2016 & -1 & -1 & 0 & -1 & +1 & +1 \\
\hline Hacker et al & 2017 & +1 & +1 & 0 & -1 & +1 & 2 \\
\hline Persoon,et al & 2017 & +1 & +1 & 0 & -1 & +1 & 2 \\
\hline Schumacher et al & 2018 & +1 & +1 & 0 & -1 & +1 & 2 \\
\hline
\end{tabular}


Tab'a 5 Yarious reported outcomes from the exercise interventions

\begin{tabular}{|c|c|c|}
\hline Aut 10i $x$ aar of study & Main Parameter & Outcome \\
\hline Mello, T taka Dulley (2003) & Muscle strength & Exercises are efficient in promoting an increase in muscle strength \\
\hline $\operatorname{Kim} \& \operatorname{Kim} 2 \overline{00^{c}}$, & Anxiety and Depression & Relaxation breathing exercise can improve anxiety and depression levels \\
\hline Coleman et al (2us & $\mathrm{Hgb}$ & Exercise can help decrease the need for transfusions. \\
\hline Jarden et al (2009) & $\begin{array}{l}\text { Diarrhoea, } \\
\text { QOL, } \\
\text { F- tigue \& } \\
\text { syc ological wellbeing }\end{array}$ & $\begin{array}{l}\text { Exercise can help decreased intensity of diarrhoea and days receiving TPN while undergoing allo-HSCT, } \\
\text { improve QOL, fatigue and psychological well-being up to } 6 \text { months after allo-HSCT. }\end{array}$ \\
\hline Shelton et al (2009) & Functional capacity & $\begin{array}{l}\text { Short-term exercise training regardless of how the training program is supervised can help improve patient } \\
\text { functional capacity. }\end{array}$ \\
\hline Chamorro-vin et al (2010) & Immune cell recovery \& BMI & $\begin{array}{l}\text { Moderate-intensity exercise training does not negatively affect immune cell recovery in children with high- } \\
\text { risk cancer while contributing to increasing body mass and BMI. }\end{array}$ \\
\hline Baumann et al (2011) & $\begin{array}{l}\text { physiological, psychological, } \\
\text { and } \\
\text { psychosocial }\end{array}$ & $\begin{array}{l}\text { Physical exercise was found to be feasible and safe with positive impact on patient's physiological, } \\
\text { psychological, and psychosocial constitution. }\end{array}$ \\
\hline Wiskemann et al (2011) & Strength and functional capacity & Exercises had no major benefit on strength and functional capacity \\
\hline Knols et al (2011) & $\begin{array}{l}\text { Health-related quality of life } \\
\text { and fatigue }\end{array}$ & Physical exercise has a positive impact on the health-related quality of life and fatigue. \\
\hline Tran et al (2012) & Respiratory & $\begin{array}{l}\text { Pulmonary rehabilitation appears to improve 6-minute walk distance, subjective symptoms of dyspnoea and } \\
\text { exercise tolerance in patients with Bronchiolitis obliterans syndrome }\end{array}$ \\
\hline Morishita et al (2013) & $\begin{array}{l}\text { Cytopenia } \\
\text { Quality of Life } \\
\text { Physiological function }\end{array}$ & $\begin{array}{l}\text { Physical therapt was found to be safe and beneficial in cytopenic patients and can help improve physiological } \\
\text { function and QOL. }\end{array}$ \\
\hline Wiskemann et al (2014) & Physical fitness and fatigue. & $\begin{array}{l}\text { No significant beneficial effects of the supervised high-intensity exercise program on physical fitness and } \\
\text { fatigue. }\end{array}$ \\
\hline Jacobsen et al (2014) & Muscle mass & Exercise therapy can help to maintain lower extremity muscle mass. \\
\hline Takekiyo et al (2015) & $\begin{array}{l}\text { Muscle Strength, Fatigue, } \\
\text { Functional capacity }\end{array}$ & $\begin{array}{l}\text { Strength training intervention can enhance early recovery after HCT; reduce fatigue while maintaining and/or } \\
\text { improving muscle strength and functional ability. }\end{array}$ \\
\hline Hacker et al (2016) & $\begin{array}{l}\text { Quality of Life and } \\
\text { Fatigue }\end{array}$ & Structured physical activity program has positive effects on QOL and fatigue scores \\
\hline Kabak et al (2016) & Cardiorespiratory fitness & $\begin{array}{l}\text { Home-based, personalized intensive exercise programs have the potential to improve cardiorespiratory } \\
\text { fitness. }\end{array}$ \\
\hline Wood et al (2016) & $\begin{array}{l}\text { Fatigue, Physical performance } \\
\text { and functional capacity. }\end{array}$ & $\begin{array}{l}\text { Physical exercise is beneficial for patients before, during, and after allo-HSC } \bar{T} \text {, can significantly alter cancer- } \\
\text { related fatigue in the context of allo-HSCT, improve physical performance and functioning. }\end{array}$ \\
\hline Persoon, et al (2017) & $\begin{array}{l}\text { Strength, endurance, quality of } \\
\text { life and fatigue }\end{array}$ & No significant difference between supervised and unsupervised exercise group \\
\hline Schumacher et al (2018) & $\begin{array}{l}\text { Endurance } \\
\text { Strength } \\
\text { Quality of life }\end{array}$ & $\begin{array}{l}\text { Exercise had favourable effect on physical } \\
\text { fitness, fatigue, and QoL and exergaming is capable of eliciting physical activity intensity } \\
\text { similar to that of moderate exercise }\end{array}$ \\
\hline
\end{tabular}

